\title{
Antioxidants and Hepato Protective Potentials of Oral Cleome Brachycarpa Hydroalcoholic Extract: An Organ Toxicity Assessment in Mice
}

\author{
Sahar Jorshabani ${ }^{1}$, Fatemeh Bagheri ${ }^{1}$, Jinous Asgarpanah ${ }^{2}$, Sepideh Arbabi Bidgoli ${ }^{1,3 *}$ \\ ${ }^{1}$ Pharmaceutical Sciences Research Center, Pharmaceutical Sciences Branch, Islamic Azad University \\ (IAUPS), Tehran, Iran. \\ ${ }^{2}$ Department of Pharmacognosy, Faculty of Pharmacy, Pharmaceutical Sciences Branch, Islamic \\ Azad University (IAUPS), Tehran, Iran. \\ ${ }^{3}$ Departments of Toxicology \& Pharmacology, Pharmaceutical Sciences Branch, Islamic Azad \\ University (IAUPS), Tehran, Iran.
}

\begin{abstract}
:
Aims and Objectives : Other species of cleome have showed hepato protective properties but there is no study on safety profile and xenobiotic induced hepato protective activities of Cleome brachycarpa which have showed many other pharmacological properties. This study aimed to evaluate the acute and subchronic oral toxicity of the hydroalcoholic extract of the aerial parts of Cleome brachycarpa to provide its safe dose and to compare the possible antioxidant and hepato protective potentials on acetaminophen-induced hepatotoxicity with Silybum Marianum as an approved hepatoprotective agent in global markets.

Method and Materials: After providing the hydroalcoholic extract, acute and repeated doseoral toxicity assessments were performed by OECD 425 and 407 guidelines. In hepatoprotection assessments, animals were divided to 4 gorups for 6 days interventions. Negative and positive controls received $10 \mathrm{ml} / \mathrm{kg}$ normal saline and $500 \mathrm{mg} / \mathrm{kg}$ acetaminophen respectively. In 2 treatment groups animals received $100 \mathrm{mg} / \mathrm{kg}$ from the hydroalcoholic extract of C.brachycarpa and $200 \mathrm{mg} / \mathrm{kg}$ Silybum marianum (Silymarin) extract .All treatment groups received $500 \mathrm{mg} / \mathrm{kg}$ acetaminophen on the $5^{\text {th }}$ day, one hour after the last pretreatment with two different hepato protective agents. On the $6^{\text {th }}$ day, liver injuries and the quality of hepato protection were assessed by ALT, AST, ALP, SOD, CAT, and MDA in liver tissues and histopathologicalstudies.

Results: Acute test didn't show any sign of toxicity in doses up to $5000 \mathrm{mg} / \mathrm{kg}$ and in repeated dose test, no sign of organ toxicity was detected in doses up to $250 \mathrm{mg} / \mathrm{kg}$.Pretreatment with C. brachycarpa extract (100 mg/kg) exhibited a significant reduction in ALT, AST, ALP and MDA $(p<0.05)$ levels when compared with the acetaminophen-only treated group. At the same time, pretreatment with C.brachycarpa extract $(100 \mathrm{mg} / \mathrm{kg})$ caused a significant increase in the levels of SOD and Catalase $(p<0.05)$ in comparison to the acetaminophentreated group. Silymarin treated mice showed similar effects except for Catalase levels which were better controlled by $C$. brachycarpaextract. The complete histopathological study and liver scores confirmed the biochemical data.

Conclusion: This study has revealed the safety and hepato protective effects of Cleome brachycarpa herbal extract as a possible new pharmaceutical dosage form for future studies which could be considered as a new effective supplement in xenobiotics-induced liver damages.
\end{abstract}

Keywords: Cleome brachycarpa; Hepatotoxicity, Hepato protection, oxidative stress; MDA; Silymarin

List of Abbreviations:

ALP: Alkaline phosphatase

ALT: Alanine Amino transferase

APAP: N-Acetyl-p-Aminophenol

AST: Aspartate Aminotransferase

CAT: Catalase

CCAC: Canadian Council on Animal Care

DPPH: 1, 1-Diphenyl-2-picryl-hydrazyl

FRAP: Fluorescence recovery after photobleaching

$H \& E$ : Hematoxylin and Eosin dye 
Sahar Jorshabani et al.

IAUPS: Islamic Azad University, Pharmaceutical Sciences Branch

MDA: Malondialdehyde

SOD: Superoxide Dismutase

OECD: Organization for Economic Co-operation and Development

OBWI: Organ Body Weight Index

NAPQI: N-acetyl-p-benzoquinone imine

NIH: National Institutes of Health

\section{BACKGROUND}

More than $10 \%$ of the human populations are affected by sustained exposure to certain hepatotoxic agents, like alcohol, viruses, parasites, toxic substances and bio transformed metabolites which may finally develop to cirrhosis or hepatocellular carcinoma (HCC) [1]. Liver is a high-risk organ for toxic reactions because liver injuries are closely connected to inflammation, which is the innate defense system of the body for removing harmful stimulus [2]. As the pathogenesis of liver diseases is associated with inflammation and Oxidative stress, herbals with anti-inflammatory and anti-oxidative properties may have potential values in prevention and protection from toxic injuries and they may calledas the main sources of new chemical substances with potential therapeutic effects in xenobioticinduced liver injuries[3].

Cleome brachycarpafrom the family of Cleomaceae has a wide distribution in sandy regions of Africa and Asia, especially in North Africa, Egypt, Saudi Arabia, Afghanistan, Pakistan, India, and Hormozgan province of Iran [4]. These species are called Spider flowers because of their special shape of flowers but they are becoming rare nowadays and only small populations from this plant with a restricted distribution have remained in India.

Other species of cleomes howed vermicide, analgesic and antiemetic effects [5] as well as hepato protective properties [6] , [7].They have been used in Iranian traditional medicine for treatment of jaundice, diarrhea, fever, infections, bronchitis, scabies, malaria, heart failure, immune system deficiency, seizure and rheumatoid arthritis [8] moreover in a recent study antioxidant effects of C.brachycarpa ethanolic extract from stems, roots and leaves have been suggested [9]. Total phenolic and flavonoid contents in all three parts of the plant showed high DPPH radical scavenging and FRAP activities [6].Furthermore, another research has established in vitro antibacterial effects of aerial parts[8], memory boosting effects in Alzheimer [10], and anxiolytic effects in CNS [11]. As the flavonoid and sesquiterpene constituents of the aerial parts of $C$. brachycarpa have shown cytotoxic effects, this plant might be considered as anantitum or agent in the future [12].

N-Acetyl-p-Aminophenol (APAP) known as acetaminophen is a widely used nonprescription analgesic and antipyretic drug that has a very low rate of liver toxicity at normal therapeutic doses; however, it causes hepatic and renal injuries in human and experimental animals when administered in high-risk people or at high dose levels [13].The liver metabolizes acetaminophen in the form of glucuronide and sulfate with urinary excretion [14], but small fractions of the administered dose could be metabolized by CYP450 isotypes (cyp2 E1) to a reactive free radical, n-acetyl-pbenzoquinone imine (NAPQI) [15]. This metabolite is a strong electrophile with oxidizing properties which normally detoxified by reduced glutathione $(\mathrm{GSH})$ in the liver [16]. In acetaminophen overdoses, drug interactions, CYP450 inductions by alcohol and drug consumptions and presences of other background factors the glucuronidation and sulfation pathways become saturated, and more acetaminophen becomes available for activation by the CYP450 isoenzymes, which produces a large amount of NAPQI that causes rapid depletion of GSH levels. Then, NAPQI metabolite binds covalently to cellular macromolecules that result in massive hepatic necrosis [17], [18].

Objectives : Herbal products with hepatoprotective and antioxidants properties have played valuable roles in the treatment of chemical-induced liver toxicities such as Silymarin which is obtained from Silybum Marianum [19].This study was carried out to evaluate the toxic potentials of this extract as well as to compare the antioxidant and hepato protective potentials of hydroalcoholic extract of C.brachycarpa on acetaminophen-induced hepatotoxicity with Silybum marianum as an approved hepatoprotective agent in global markets. 


\section{MATERIALS AND METHODS}

\section{Collection and Identification of Plant Material}

Aerial parts of Cleome brachycarpawere obtained in October 2015 from Hormozgan province, south of Iran. The voucher specimen of the plant was issued at the Herbarium of Islamic Azad University pharmaceutical Sciences Branch (IAUPS), Tehran, Iran, under the voucher number of 1573_AUPF.

\section{Chemicals}

- Acetaminophen powder was obtained from DarouPakhsh Mfg. Co. (St. Darou Pakhsh, Tehran, Iran).

- Silymarin was obtained from Silybum Marianum extracts product, (Liver golß) from GolDaru Mfg. Co. (St. Shiraz, Isfahan, Iran). Liver gol® (batch No.1132) coated tablets contain dried extract of Silybum marianum 190-195 mg (equivalent to $140 \mathrm{mg}$ Silymarin).

- All other chemicals and kits were purchased from Merck laboratories, Darmstadt, Germany. Solvents used throughout this investigation obtained from the highest commercially available analytical grade while the water was glass distilled.

\section{Plant Extract Preparation}

Aerial parts of the plant were extracted by Maceration method. In this method, the plant material was placed in a container full of menstruum (ethanol $80^{\circ}$ ) and remained for three to four days and were shaken frequently until complete extraction of plant material. After this phase of extraction, the plant material was strained and the remaining solid was squeezed to remove all the remaining liquid. The obtained liquid was clarified by filtration. Then the extract was placed at room temperaturesince all amount of solvent evaporated and solid extract kept in the refrigerator [20]. For oral administrations, this extract dissolved in normal saline then used by gavages according to the required doses of 100 $\mathrm{mg} / \mathrm{kg}$ body weight for 5 continues days.

\section{Experimental Animals and Housing Conditions}

Studies were carried out using male mice (6-8 weeks old, 25-30 g), obtained from Animal house of Pasteur Institute of Iran. Mice were kept in cages under standard condition (temperature $25 \pm 2^{\circ} \mathrm{C}$ ) with 12 hours light/dark cycle. They were provided with standard pellet diet and free access to drinking water ad libitum. The animals were acclimatized to the environment for a week before the commencement of the experiment. An investigation using experimental animals contained a statement confirming the adherence of the research to the Principles of Laboratory Animal Care published by NIH [21] and approved by the ethical committee of IAUPS.

\section{Part I: Toxicological Evaluations}

\section{Acute Qral Toxicity Test}

In this study, single oral doses ofplant extract $(5000 \mathrm{mg} / \mathrm{kg})$ were administered by oral gavages to 6 female and 6 male mice afterthe randomized division of animals to two groups( 6 animals in each group). Mice were observed for mortality and any sign of toxicity for 14 hours and also signs of toxicity and weight changes were investigated during 14 daily follow-up protocol. This study was done according to OECD 425 toxicity assessment guideline [22,23].

\section{Repeated Dose Oral Toxicity Study}

Twenty-fivemice were randomly divided into 5 groups (5 mice in each group; $25,250,500,1000 \mathrm{mg} / \mathrm{kg}$ and control).All the groups were administered orally from the plant extract on the basis of their body weights once daily for 6 days per week over a period of 28 days .Control groups received equal volumes of distilled water daily. This study was done according to OECD 407 toxicity assessment guideline [24].

\section{Part II: Study of Hepato Protective Potentials}

\section{Grouping of Animals}

In order to investigate the hepatoprotective effects of C.brachycarpa hydro alcoholic extract in mice, the mice were divided into the following groups each containing 6 mice:Group1: negative control group: which were fed (gavage) normal saline 10 $\mathrm{ml} / \mathrm{kg}$ for 5 days; Group2:acetaminophen treated group: which were fed normal saline $10 \mathrm{ml} / \mathrm{kg}$ for 5 days, on the fifth day one hour after the last administration, administered orally $500 \mathrm{mg} / \mathrm{kg}$ acetaminophen; Group3: positive control group which 
were fed Silymarin $200 \mathrm{mg} / \mathrm{kg}$ for5 days, on the fifth day one hour after the last administration, administered orally $500 \mathrm{mg} / \mathrm{kg}$ acetaminophen. Group4: extract treated group, orally received a hydroalcoholic extract of $C$. brachycarpa $100 \mathrm{mg} / \mathrm{kg}$ for 5 days, on the fifth day one hour after the last administration, administered orally $500 \mathrm{mg} / \mathrm{kg}$ acetaminophen. Mice weights recorded through 6days, then on the sixth day animals were sacrificed.

\section{Administration of Acetaminophen}

The acetaminophen liver toxicity model was previously described by Forouzandeh Hossein et al [25] with necessary modifications. Acetaminophen was first dissolved in normal saline at $70^{\circ} \mathrm{C}$ and then cooled down to $37^{\circ} \mathrm{C}$ for oral administration. It was administered in a single oral dose of $500 \mathrm{mg} / \mathrm{kg}$ on the $5^{\text {th }}$ day of interventions just one hour after the last administration of study subjects.

\section{Preparation of Plasma and Liver Homogenate}

On the $6^{\text {th }}$ day of study, animals were anesthetized with ether and sacrificed instantly. Three blood samples were undertaken from the hearts of 3 animals of all treatment groups and collected in sterilized centrifuge tubes. The blood samples were then allowed to coagulate at $30^{\circ} \mathrm{C}$ for 45 minutes. Serum portion was separated from each sample by centrifugation at $25000 \mathrm{~g}$ at $30^{\circ} \mathrm{C}$ for 10 minutes and subjected to the biochemical investigation to assess liver function tests [26].Then the livers were dissected immediatelyand weighed for liver Organ Body Weight Index (OBWI) estimations and at the second, livers were divided into two equal parts. One part was homogenized in $50 \mathrm{mM}$ phosphate buffer (PH 7.4) and centrifuged at $32000 \mathrm{~g}$ for $20 \mathrm{~min}$ at $4^{\circ} \mathrm{C}$, the supernatant was separated, which were used to measure enzymes and tissue peroxidation [27].The remaining parts of the liver were used for histological studies.

\section{Biochemical Analyses}

Biochemical analyses were carried out on Serum Amino transaminases (ALT and AST) and Alkaline phosphatase (ALP). ALT and AST in serums were determined by the method of Reitman-Frankel. In this procedure, transaminase reacts with 2, 4-dinitrophenyl hydrazones reagent and produces acolor complex that is proportional to the AST and ALT levels [28] .ALP has estimated also according to end point method.

\section{Antioxidant Assays}

The Malondialdehyde (MDA) factor, an index of lipid peroxidation factor was determined by Buge\& Aust method, (with thiobarbituric acid) [29].The Superoxide dismutase (SOD) factor was also calculated according to Maklund S. Ref method [30] .Finally, the Catalase (CAT) levels were determined according to Goth L. method [31].

\section{Histopathological Assessments}

Table 1. Evaluation criteria and scoring method for the assessment of liver histopathological effects.

\begin{tabular}{|c|c|c|}
\hline Histopathological effects & Evaluation criteria & scores \\
\hline \multirow{4}{*}{ Vacuolar degeneration } & $<5 \%$ & 1 \\
\cline { 2 - 3 } & $5 \%-33 \%$ & 2 \\
\cline { 2 - 3 } & $33 \%-66 \%$ & 3 \\
\cline { 2 - 3 } & $>66 \%$ & 1 \\
\hline \multirow{4}{*}{ Necrosis } & No necrosis & 2 \\
\cline { 2 - 3 } & $1-3$ Necrotic cells & 3 \\
\cline { 2 - 3 } & $3-6$ Necrotic cells & 4 \\
\cline { 2 - 3 } Inflammation \& Increase of & $>6$ Necrotic cells & 1 \\
\cline { 2 - 3 } kupffer cells & No inflammation & 2 \\
\cline { 2 - 3 } & Mild & 3 \\
\cline { 2 - 3 } & Moderate & 4 \\
\hline Total & Severe & - \\
\hline
\end{tabular}

Liver sections from different groups of mice were fixed in $10 \%(\mathrm{w} / \mathrm{v})$ buffered formalin and used for histological studies. For histopathological studies, liver tissues were dehydrated with ethanol solutions, cut into5-micron sections by microtome, stained with Hematoxylin and Eosin dye (H\&E) and observed under a photomicroscope by x100 and x400 magnifications. The observed morphological changes included: cell necrosis, vacuolar degeneration, inflammation and increased number of kupffer cells. The methodof scoringwas described in Table 1. 


\section{Statistical Analysis}

Statistical analysis was performed using the statistical package SPSS for windows. The results were expressed as mean \pm SD. One-way ANOVA followed by Tukey post-test were applied for statistical analysis with the level of significance set at $\mathrm{p}<0.05$.

\section{RESULTS}

\section{Part I: Toxicity Evaluations}

\section{Acute Oral Toxicity Studies}

Recording clinical signs, no death and no sign of toxicity were recorded in the first 24 hours of administrations using plant extract. Normal physical activities were recorded in all animals during the next 14 days follow-up period.

\section{Repeated Dose Toxicity Study}

\section{Survival and Clinical Signs}

Animals survived healthy in dose groups of 250,500 and $1000 \mathrm{mg} / \mathrm{kg}$ for 28 days period of study in water as a solvent group. Normal physical activities were recorded in all animals during this period of study.

\section{Total Body Weights}

The trends of weight gains were similar in all low, medium and high dose treatment groups when compared with control(Fig 1).The levels of water and food consumption during this 18 day study was similar $(P>0.05)$.

\section{Necropsy Studies}

After careful considerations, absolute and relative weights of heart, kidney, liver, ovaries, lungs and uterus were recorded at the endpoint of study. The absolute and relative weights of all organs remained unchanged from corresponding control groups and no gross changes wereobserved.

\section{Histopathological Studies}

Pathological studies were performed at day 28 on all resected organs of $1000,500,250 \mathrm{mg} / \mathrm{kg}$ doses.

\section{- Liver}

In hepatic tissues of high dose group $(1000 \mathrm{mg} / \mathrm{kg})$ partial necrosis of hepatocytes were seen in one animal the rest of animals didn't show any sign of liver toxicity (Fig 1A, 1B).

Fig 1. Organ effects of Cleome Brachycarpahydro alcoholic extract in low, medium and high dose groups.

\section{A: Liver}

Liver showed normal structure without focal infiltration of mononuclear cells. Liver sections showed increased kupffer cells and normal nucleuses even in high dose groups (H\&E x100, 400)

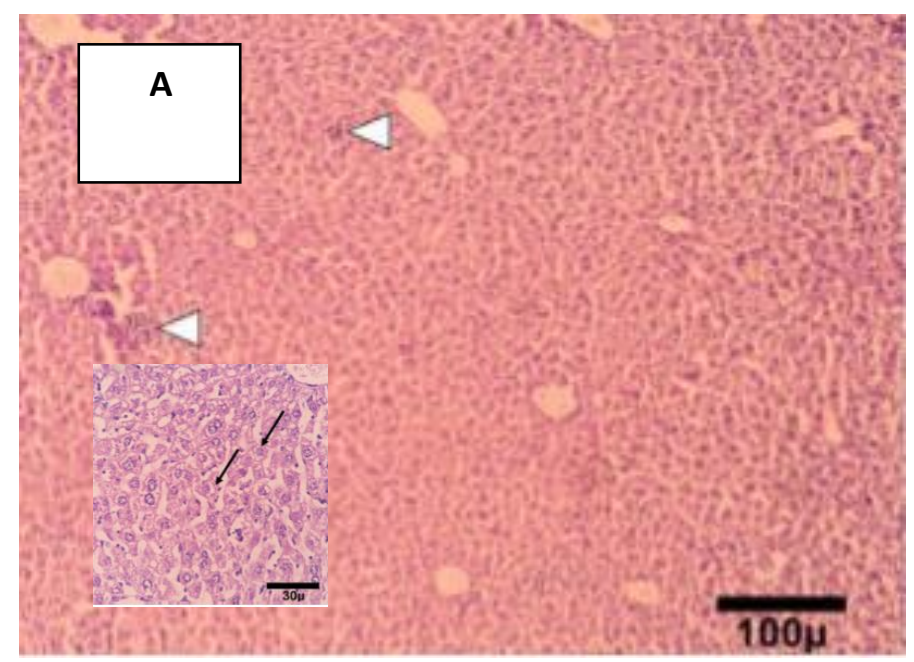


Sahar Jorshabani et al.

\section{B: Kidney}

Normal structure of kidney in high dose group without histopathological abnormality (H\& E x100)

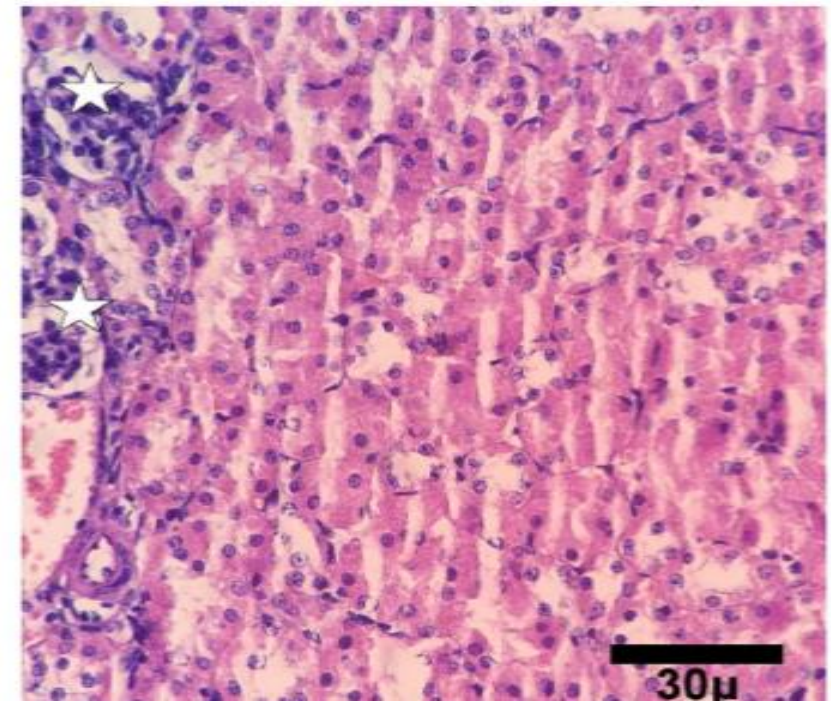

\section{- Lungs}

In pulmonary tissues of high dose group $(1000 \mathrm{mg} / \mathrm{kg})$ accumulation of mononuclear cells in the alveolar duct and mild congestion were detected.Pulmonary tissues of lower doses remained normal (Fig 1C).

\section{C: Heart}

Normal structure of heart in high dose group without histopathological abnormality (H\&E x100, 400)

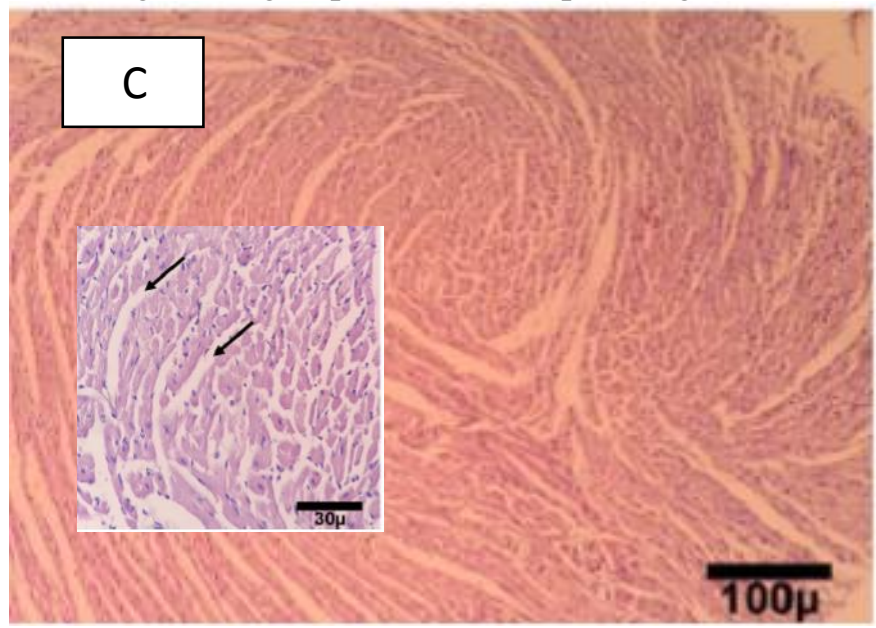

\section{E: Ovary}

Normal structure of Ovaries in high dose group ((H\&E x100)

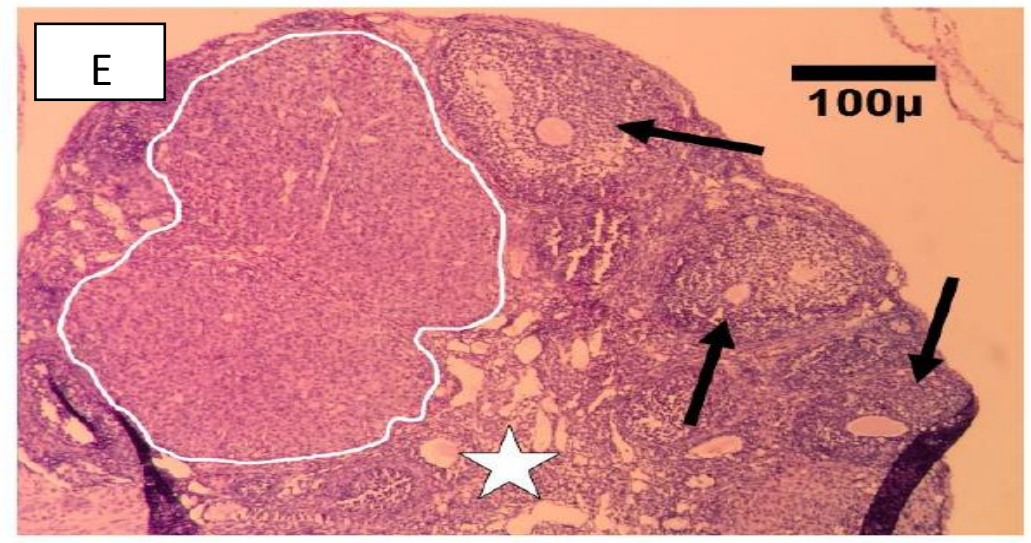


Antioxidants and Hepato Protective Potentials of oral Cleome Brachycarpa Hydroalcoholic Extract: An Organ Toxicity Assessment in Mice

\section{F: Spleen}

Normal structure of spleen in high dose group without any histopathological feature (H\&E, X100

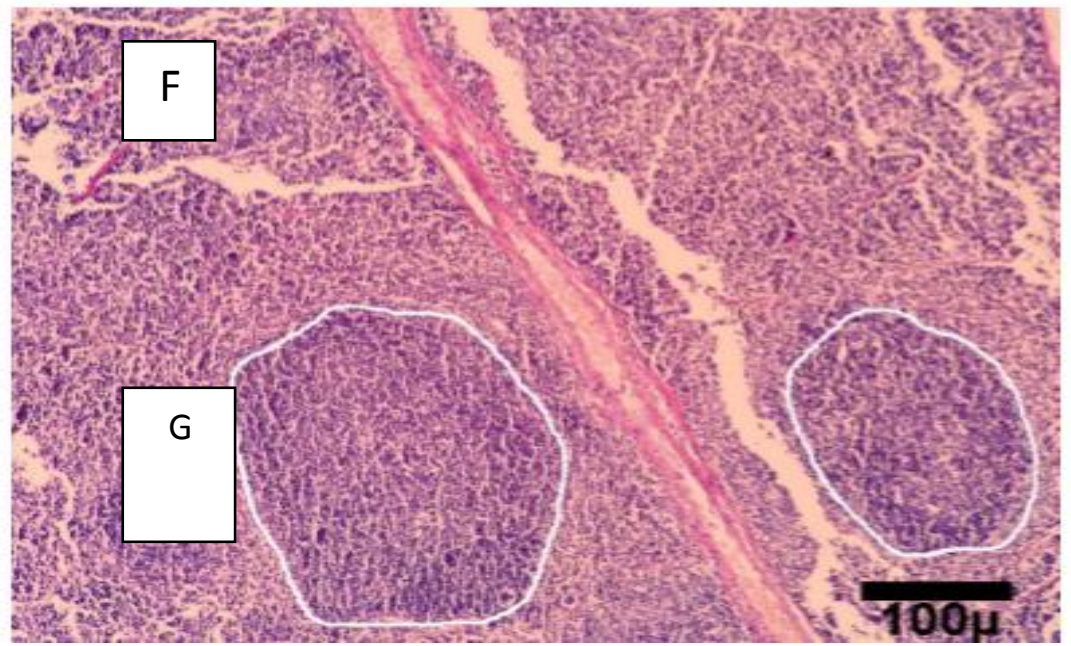

\section{G: Uterus}

Normal structures of endometrium (E), myometrium(M) and perimetrium $(\mathrm{P})$ of high dose group.

\section{- Kidneys}

Mild degeneration of proximal tubules and renal tissue with epithelial necrosis in proximal tubule was recognized in high dose group. Hydropic degeneration of proximal tubules in $500 \mathrm{mg} / \mathrm{kg}$ and multifocal mononuclear cells infiltration in $250 \mathrm{mg} / \mathrm{kg}$ dose groups were identified too (Fig 1D).

D: Normal structure of lungs in high dose group (H\&E x100, 400)

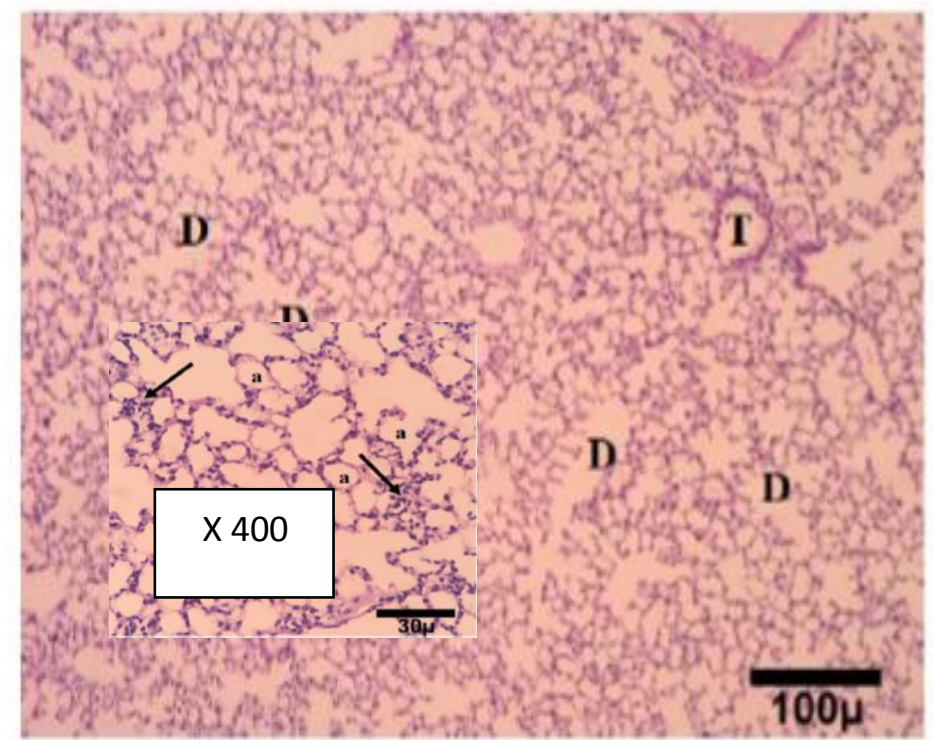

\section{- Hearts}

Normal structures were seen in the hearts of animals in different dose groups.

\section{- Uterus}

Although mild edema in endometrium and moderate edema in perimeter layer of low and medium doses observed, respectively, the surface of endometrial epithelium was hyperplastic in high dose group.

\section{- Ovary}

\section{Part II: Hepato Protection and Antioxidant Assessment}




\section{Plasma Marker Enzymes}

As described in Table 1, serum levels of AST, ALT and ALP were considered as biomarkers of liver function due to acetaminophen-induced hepatotoxicity. Table 1 shows the acetaminophen-induced liver toxicity by significant raise of three mentioned biomarkers. Acetaminophen-treated mice developed significant hepato cellular damages as they are evident from significant $(p<0.05)$ increases in the serum activities of ALT, AST, ALP when compared with the negative control group. At the same time pretreatment with C.brachycarpa extract $100 \mathrm{mg} / \mathrm{kg}$ as test material and Silymarin 200 $\mathrm{mg} / \mathrm{kg}$ as a standard drug, exhibited significant $(\mathrm{p}<0.05)$ reductions in the levels of AST, ALT, and ALP when compared with the acetaminophen-treated group.

\section{Antioxidant and Lipid Peroxidation Biomarkers}

Table 2 shows MDA, SOD and CAT levels in acetaminophen-induced hepatotoxicitymodel:

Table 2. Protective roles of hydroalcoholic extract of the aerial parts of Cleome brachycarpa against Acetaminophen induced liver toxicity

\begin{tabular}{|c|c|c|c|c|c|c|c|}
\hline Groups & Treatment & AST (U/L) & ALT (U/L) & ALP (U/L) & $\begin{array}{l}\text { SOD } \\
\text { (U/mg- } \\
\text { Protein) }\end{array}$ & \begin{tabular}{|l|} 
CAT \\
$(\mu M o l / m g-$ \\
Protein $)$
\end{tabular} & $\begin{array}{l}\text { MDA } \\
\text { (nMol/gProtein) }\end{array}$ \\
\hline $\begin{array}{l}\text { 1.Negetiv } \\
\text { e control }\end{array}$ & $\begin{array}{lll}\text { Normal } & \text { saline } & 10 \\
\mathrm{ml} / \mathrm{kg} & & \\
\end{array}$ & $148.37^{\mathrm{b}} \pm 4.22$ & $103.10^{\mathrm{b}} \pm 7.73$ & $343.50^{\mathrm{b}} \pm 5.77$ & $20.08^{\mathrm{b}} \pm 1.10$ & $0.28 \pm 0.01$ & $1.93^{\mathrm{b}} \pm 0.09$ \\
\hline $\begin{array}{l}\text { 2.Acetam } \\
\text { inophen } \\
\text { treated }\end{array}$ & $\begin{array}{l}\text { Normal saline } 10 \\
\mathrm{ml} / \mathrm{kg}+\mathrm{Acetaminophe} \\
\mathrm{n} 500 \mathrm{mg} / \mathrm{kg}\end{array}$ & $164.01^{\mathrm{a}} \pm 4.58$ & $125.80^{\mathrm{a}} \pm 2.31$ & $379.37^{\mathrm{a}} \pm 9.50$ & $16.36^{\mathrm{a}} \pm 0.57$ & $0.21 \pm 0.03$ & $3.05^{\mathrm{a}} \pm 0.07$ \\
\hline $\begin{array}{l}\text { 3.Positiv } \\
\text { e control }\end{array}$ & $\begin{array}{l}\text { Silymarin } \\
200 \mathrm{mg} / \mathrm{kg}+ \\
\text { Acetaminophen } 500 \\
\mathrm{mg} / \mathrm{kg}\end{array}$ & $143.81^{\mathrm{b}} \pm 7.28$ & $100.48^{\mathrm{b}} \pm 2.45$ & $311.50^{\mathrm{ab}} \pm 19.56$ & $19.70^{\mathrm{b}} \pm 0.23$ & $0.26 \pm 0.00$ & $1.84^{\mathrm{b}} \pm 0.15$ \\
\hline $\begin{array}{l}\text { 4.C.brac } \\
\text { hycarpa } \\
\text { extract }\end{array}$ & $\begin{array}{l}\text { C.brachycarpa } \\
\text { extract } \\
100 \mathrm{mg} / \mathrm{kg}+ \\
\text { Acetaminophen } 500 \\
\mathrm{mg} / \mathrm{kg}\end{array}$ & $144.10^{\mathrm{b}} \pm 9.80$ & $101.66^{\mathrm{b}} \pm 3.05$ & $320.07^{\mathrm{b}} \pm 8.65$ & $18.41^{\mathrm{b}} \pm 0.46$ & $0.34^{\mathrm{bc}} \pm 0.04$ & $1.71^{\mathrm{b}} \pm 0.11$ \\
\hline
\end{tabular}

Each value represents the mean $\pm S D$ for six mice. ${ }^{a}$ : Significantly different from the negative control group at $p$ $<0.05{ }^{b}$ : Significantly different from acetaminophen treated group at $p<0.05 .{ }^{c}$ : Significantly different from the positive control group at $p<0.05$.

MDA: After quantitative measurements, MDA analysis showed asignificant increase in comparison to negative control group $(\mathrm{p}<0.05)$. At the same time, pretreatment with $C$. brachycarpa extract at doses of $100 \mathrm{mg} / \mathrm{kg}$ and Silymarin pretreatment at doses of $200 \mathrm{mg} / \mathrm{kg}$ exhibited significant reductions in MDA levels $(\mathrm{p}<0.05)$.

SOD: The result of SOD analysis showed asignificant decrease when compared with negative control group $(\mathrm{p}<0.05)$ but pretreatment with C.brachycarpa extract and Silymarin exhibited significantly and similar reductions in SOD concentrations $(\mathrm{p}<0.05)$.

CAT: The result of CAT analysis didn't show any significant change in all groups even in Silymarin treated mice in comparison to the negative control group. Pretreatment of mice with C.brachycarpa extract caused asignificant increase in CAT levels incomparison to Acetaminophen and Silymarin treated groups $(\mathrm{p}<0.05)$.

\section{Liver Weights and Organ Body Weight Index (OBWI)}

Liver weights of mice measured at the $6^{\text {th }}$ day of study. Table 3 demonstrates liver weights of mice in acetaminophen-induced hepatotoxicity. The results exhibited that the Liver OBWI in the acetaminophen-treated group was significantly decreased in comparison to the normal liver in the control group ( $42 \pm 0.001 \mathrm{mg} v s .61 \pm 0.008 \mathrm{mg}, p<0.05)$. Conversely, pretreatments with Silymarin $200 \mathrm{mg} / \mathrm{kg}$ and C.brachycarpa $100 \mathrm{mg} / \mathrm{kg}$ resulted in normalization of the Liver OBWI when compared with acetaminophen treated group $(70 \pm 0.005 \mathrm{mg} v s .60 \pm 0.004 \mathrm{mg}, p<0.05)$. This could possibly be the result of the incidence of acute necrosis in the hepatocytes in the absence of adequate levels of hepatoprotective agents. In fact, both plant extracts supported the liver parenchymal cells growth and normalizedthe Liver OBWI. 
Antioxidants and Hepato Protective Potentials of oral Cleome Brachycarpa Hydroalcoholic Extract: An Organ Toxicity Assessment in Mice

Table 3. Effect of hydroalcoholic extract of the aerial parts of Cleome brachycarpa on Acetaminophen induced changes in the liver and body weights.

\begin{tabular}{|c|c|c|c|c|}
\hline Groups & Treatment & Liver OBWI(mg) & $\begin{array}{c}\text { Average body } \\
\text { weight pre } \\
\text { administration } \\
\text { (g) }\end{array}$ & $\begin{array}{c}\text { Average body } \\
\text { weight post } \\
\text { administration } \\
\text { (g) }\end{array}$ \\
\hline 1.Negetive control & Normal saline $10 \mathrm{ml} / \mathrm{kg}$ & $61^{\mathrm{b}} \pm 0.008$ & $24.49 \pm 2.78$ & $23.21 \pm 3.02$ \\
\hline $\begin{array}{l}\text { 2.Acetaminophen } \\
\text { treated }\end{array}$ & $\begin{array}{l}\text { Normal saline } 10 \mathrm{ml} / \mathrm{kg}+ \\
\text { Acetaminophen } 500 \mathrm{mg} / \mathrm{kg}\end{array}$ & $42^{\mathrm{a}} \pm 0.001$ & $23.65 \pm 1.86$ & $18.74 \pm 1.07$ \\
\hline 3.Positive control & $\begin{array}{c}\text { Silymarin } \\
200 \mathrm{mg} / \mathrm{kg}+ \\
\text { Acetaminophen } 500 \mathrm{mg} / \mathrm{kg}\end{array}$ & $70^{\mathrm{b}} \pm 0.005$ & $26.21 \pm 2.63$ & $27.17 \pm 2.09$ \\
\hline $\begin{array}{l}\text { 4.C.brachycarpa } \\
\text { extract }\end{array}$ & $\begin{array}{c}\text { C.brachycarpa extract } \\
100 \mathrm{mg} / \mathrm{kg}+ \\
\text { Acetaminophen } 500 \mathrm{mg} / \mathrm{kg}\end{array}$ & $60^{\mathrm{b}} \pm 0.004$ & $21.32 \pm 1.90$ & $22.15 \pm 1.39$ \\
\hline
\end{tabular}

Each value represents the mean $\pm S D$ for six mice. ${ }^{a}$ : Significantly different from the negative control group at $p$ $<0.05{ }^{b}$ : Significantly different from acetaminophen treated group at $p<0.05$.

\section{Body Weight}

Through the experiment, mice weights recorded regularly. Table 4 showed average body weight pre and post administrations in all groups. Although statistical analysis didn't show any significant difference $(p>0.05)$ in treatment groups and negative control, acetaminophen treated group showed asignificant reduction in total body weight $(\mathrm{p}<0.05)$ due to acetaminophen-induced toxicity. Two pretreatment groups with Silymarin $200 \mathrm{mg} / \mathrm{kg}$ and C. brachycarpa $100 \mathrm{mg} / \mathrm{kg}$ showed significant $(\mathrm{p}<0.05)$ increase in their total weights probably because of protective effects of these plants in acetaminophen toxicity, therefore, the mean weights of these two groups were not significantly different from the negative control group.

Table 4. Comparisons of histopathological scores in liver tissue histopathological studies.

\begin{tabular}{|c|c|c|c|c|}
\hline Groups & Administrations & $\begin{array}{l}\text { Mean } \\
\text { histopathological } \\
\text { lesions }\end{array}$ & $P$-value & \\
\hline \multirow[t]{3}{*}{ 1.Negetive control } & \multirow[t]{3}{*}{ Normal saline $10 \mathrm{ml} / \mathrm{kg}$} & \multirow{3}{*}{$5.33( \pm 1.53)$} & Group2 & 0.037 \\
\hline & & & Group3 & 0.993 \\
\hline & & & Group4 & 0.993 \\
\hline \multirow{3}{*}{$\begin{array}{l}\text { 2.Acetaminophen } \\
\text { treated }\end{array}$} & \multirow{3}{*}{$\begin{array}{l}\text { Normal saline } 10 \mathrm{ml} / \mathrm{kg} \\
+ \\
\text { Acetaminophen } 500 \mathrm{mg} / \mathrm{kg}\end{array}$} & \multirow{3}{*}{$9.67( \pm 1.53)$} & Group1 & 0.037 \\
\hline & & & Group3 & 0.026 \\
\hline & & & Group4 & 0.026 \\
\hline \multirow[t]{3}{*}{ 3.Positive control } & \multirow{3}{*}{$\begin{array}{l}\text { Silymarin } 200 \mathrm{mg} / \mathrm{kg} \\
+ \\
\text { Acetaminophen } 500 \mathrm{mg} / \mathrm{kg}\end{array}$} & \multirow{3}{*}{$5.00( \pm 2.00)$} & Group1 & 0.993 \\
\hline & & & Group2 & 0.026 \\
\hline & & & Group4 & 1.000 \\
\hline \multirow{3}{*}{$\begin{array}{l}\text { 4.C.brachycarpa } \\
\text { extract }\end{array}$} & \multirow{3}{*}{$\begin{array}{l}\text { C.brachycarpa } \\
\text { extract } 100 \mathrm{mg} / \mathrm{kg} \\
+ \\
\text { Acetaminophen } 500 \mathrm{mg} / \mathrm{kg}\end{array}$} & \multirow{3}{*}{$5.00( \pm 1.00)$} & Group1 & 0.993 \\
\hline & & & Group2 & 0.026 \\
\hline & & & Group3 & 1.000 \\
\hline
\end{tabular}

Histological Assessment of the Liver:

Table 4 compares the histological scores of liver lesions in all 4 study groups. The levels of liver lesions were comparable without observing any significant difference between C.brachycarpa, Sylimarin and negative control groups $(p>0.05)$. Figure 2 (a) and 2(b) shows the photomicrographs from the hepatic morphology of $C$. brachycarpa and acetaminophen groups. The histopathological study of liver sections in the negative and positive control groups, as well as the C.brachycarpa group showed that mice livers remained healthy and all of the microscopic structuresremained clearly identifiable with mean histological lesions of 5.00( \pm 1.00$)$ in C.brachycarpa group. Although in few cases of Silymarin and $C$. brachycarpa groups the cores remained dark, hepatocyte necrosis was not recognized and Central vein and hepatic lobules were detectable in all cases (Figures 2a). 


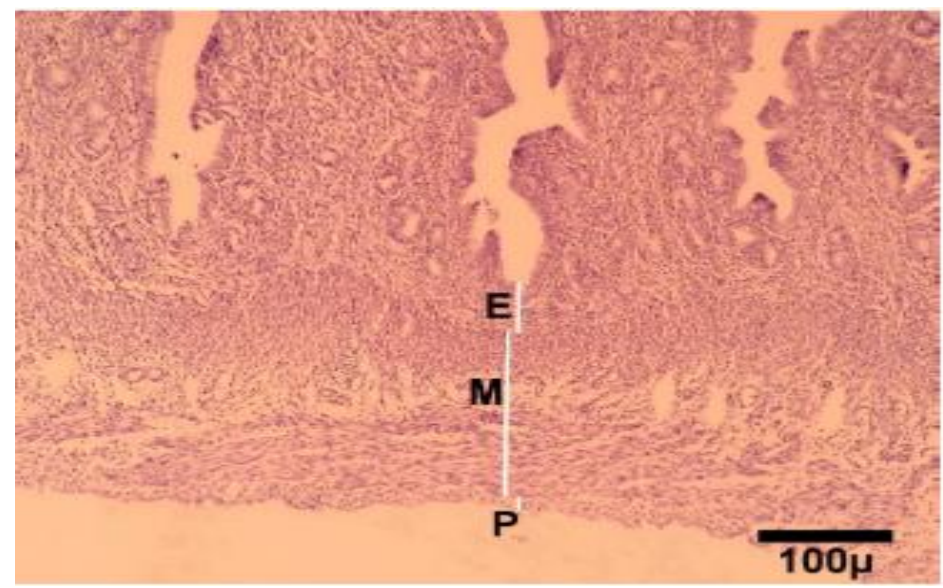

Figure 2. Photomicrograph of mice liver sections $(x 400)$

Fig 2A. Liver section of $C$. brachycarpa group (x100), liver tissue remained healthy and all of microscopic structures remained clearly identifiable. Although in a few cases the cores remained dark, hepatocyte necrosis was not recognized and Central vein and hepatic lobules was detectable.

Fig 2B. Show scattered necrosis and severe vacuole degeneration of hepatocytes with increased kupffer cells in Acetaminophen exposed group of animals.

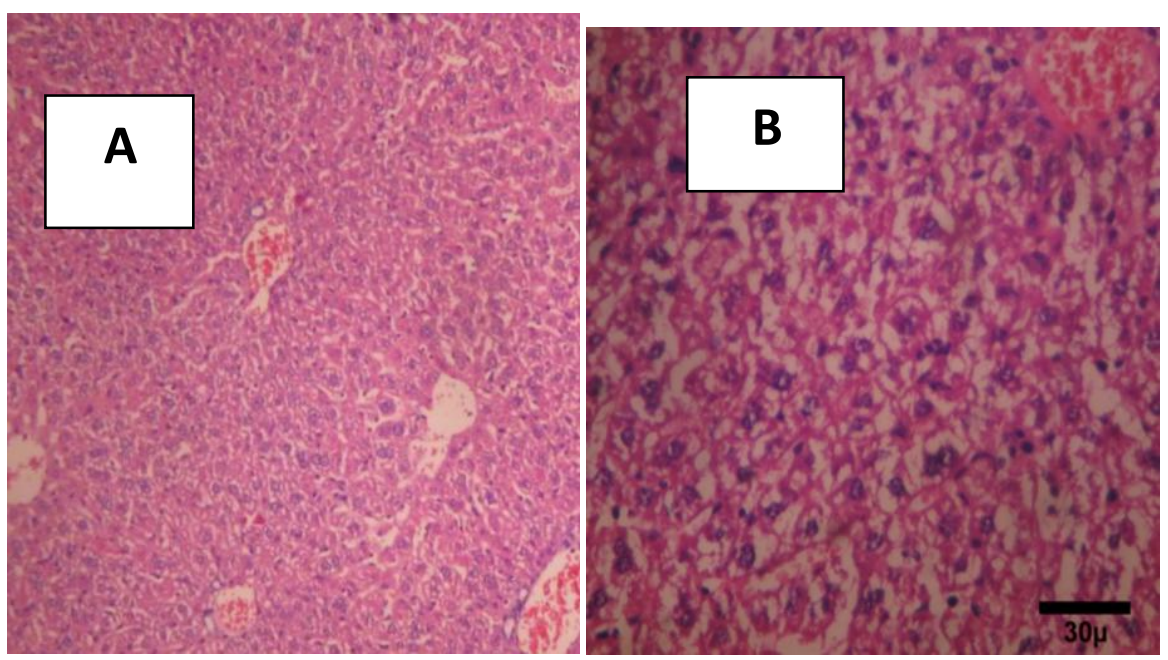

In acetaminophen group, scattered necrosis and moderate vacuole degeneration of hepatocytes with increasedkupffer cells observed with mean histological lesions of $9.67( \pm 1.53)$.

\section{DISCUSSION}

Liver is one of the largest organs in the human body and the major site for metabolism and excretion. It has a wide range of functions including, detoxifications, protein synthesis, and production of biochemical's necessary for digestion. Liver disease has become one of the major causes of morbidity and mortality in human all over the world and hepatotoxicity due to drugs appears to be the most common contributing factor in this regard [32].N-Acetyl-p-Aminophenol (APAP), also known as acetaminophen, is the most commonly used over-the-counter antipyretic and analgesic drug. APAPinduced toxicity is considered as one of the primary causes of acute liver failure; numerous scientific reports have focused majorly on APAP hepatotoxicity. A variety of rodent models of hepatoprotection has been described in which the levels of tolerance to acetaminophen-induced hepatotoxicity could be determined [33]. In fact protection against acetaminophen-induced toxicity has been used as an effective screening test for potential hepatoprotective agents by several investigations [34] which were the major concern of present study.

There are three specific and sensitive hepatotoxicity biomarkers [ Aspartate amino transferase (AST), alanine transaminase (ALT) and alkaline phosphatase (ALP)] which could be considered as promising factors because they elevate significantly and dose dependently in the serum of hepatotoxic agent treated animals when compared to control group [35].In fact, any rise in serum levels of AST, ALT, and ALP could be attributed to structural hepatocellular damages because they are normally located in 
the cytoplasm of hepatocytes and could be released into the circulation after cellular damages [36].In present study and in an attempt to identify the hepatoprotective efficacy of C.brachycarpa, the extract was prepared and subjected to the acetaminophen-induced liver injury model in mice and thehepatoprotective effects of $C$. brachycarpa were shown for the first time similar to Silymarin.

Other than the efficacy of $C$. brachycarpa in normalization of hepatotoxicity biomarkers, this extract showed significant efficacy in reducing the extent of oxidative stress by reversing the levels of MDA and SOD to normal ranges. Since hepatic damages induced by acetaminophen are mediated by its free radical metabolites, antioxidant activity or inhibition of the generation of free radicals is a very important mechanism in the body protection against acetaminophen-induced liver injury [37]). It has been reported that C.brachycarpa extract had higher antioxidant activities with concomitant higher total phenolic and flavonoid levels in all three parts (leaves, stem, root) of the plant[38]. Furthermore established hepatoprotective effects of another species of Cleome such as viscosalinn[6] cleome viscosa[39] have been suggested on the basis of their antioxidant activities. These properties motivated us to study the antioxidant activity of C.brachycarpa in acetaminophen-induced liver toxicity.

Our results in present provided strong evidence on safety of oral administration in acute and subchronic models as well as significant potencies and inhibitory effects of that $C$. brachycarpa extract exertson the acute liver toxicity induced by high doses of acetaminophen in mice as shown by significant reductions of MA and SOD. In the present experiment, MDA level decreased significantly in the treatment group and antioxidant enzymes level (SOD, Catalase) significantly increased in plant extract group. Moreover, liver histopathology, mice weights, and Liver OBWI findings confirmed the protective activity of this extract, too. The histopathological studies on the livers confirmed the protective effects of this plant against acetaminophen as it was evident from the reversal changes in scattered necrosis, vacuole degeneration and in kupffer cells production. In some cases scattered necrosis, moderate vacuole degeneration and increased kupffer cells observed confirmed its protective role. To compare the C.brachycarpa and silymarin extracts, according to studied variables, it could be concluded that there was no significant difference between silymarin and Cleome brachycarpa ( $p$ $>0.05$ ), except the efficacy of Silymarin in controlling the Catalase concentration. Catalase level was significantly $(\mathrm{p}<0.05)$ increased in plant extract group. In histopathological analysis Silymarin and plant, extract groups showed asignificant difference $(\mathrm{p}<0.05)$ with the group treated with acetaminophen, that demonstrated the effectiveness of these two agents in liver protection but the histopathological results were equal for silymarin and plant extract $(\mathrm{p}>0.05)$.

\section{CONCLUSION}

In general, it can be concluded on the basis of al reviewed factors both extracts (Silymarin $200 \mathrm{mg} / \mathrm{kg}$ and Cleome brachycarpa $100 \mathrm{mg} / \mathrm{kg}$ ) have similarhepatoprotective efficacies but in terms of potency, Cleome brachscarpaextract was twice more potent than Silymarin. In conclusion, this safe herbal extract has a protective effect on the liver and can be used as a supplement in liver damages on the basis of its lack of organ toxicity for regulatory purposes and possible commercialization as an effective supplement for liver injuries.

\section{ETHICAL APPROVAL}

The investigation was performed according to the Local Animal Ethics Committee guidelines for the use of experimental animals and was approved by ethical committee of Islamic Azad University of Pharmaceutical Sciences branch, IAUPS.

\section{REFERENCES}

[1] Das K, Mukherjee PS, Ghosh A, Ghosh S, Mridha AR et al. Nonobese population in a developing country has a high prevalence of nonalcoholic fatty liver and significant liver diseases. Hepatology. 2010 May; 51[5]:1593-602.

[2] Lam P, Cheung F, Tan HY, Wang N, Yuen MF, Feng Y. Hepatoprotective Effects of Chinese Medicinal Herbs: A Focus on Anti-Inflammatory and Anti-Oxidative Activities.Int J Mol Sci. 2016 Mar 29; 17 [4]:465.

[3] Susunaga GS, Siani AC, Pizzolati MG, Yunes R, Delle Monache F. Triterpenes from the Resin of Pirotium hepatophyllum. Fitoterapia. 2001 Aug; 72(6):709-11. 
[4] Aparadh V.T., Mahamun R.J.,Karadge B.A. Taxonomy and Physiological Studies In Spider Flower (Cleome species): A Critical Review. Plant Sciences Feed 2012 ,2[3]: 25-46.

[5] Ahmed S, Mohtasheemul Hasan M , Ahmed SW. Natural antiemetics: An overview. Pak J Pharm Sci. 2014 Sep; 27[5 Spec no]:1583-98.

[6] Gupta NK, Dixit VK. Hepatoprotective activity of Cleome viscosa Linn. extract against thioacetamide-induced hepatotoxicity in rats. Nat Prod Res. 2009; 23[14]:1289-97.

[7] Rajaraman R, Saravanan R, Dheeba B , Ramalingam S. In vivo investigation of hepatoprotective activity of Cleome viscosa L. in albino rats. Der Pharmacia Lettre 2016, 8[3]: 308-313.

[8] Pooryazdani Kojour F, AsgarpanahJ ,Mahboubi A. In vitro antibacterial activity and total phenolic and flavonoid content of Cleome brachycarpa Vahl ex DC methanol extract and its subfractions. IJGHC 2014, 3[3], 1238-1245.

[9] Ali J.K., Cheruth A. J., Salem M.A., Maqsood S.Evaluation of antioxidant activity of Cleome brachycarpa Vahl ex DC, an under-exploited desert plant of United Arab Emirates.PhOL. 2012 , $3, ; 167-173$.

[10] Gupta NK, Dixit VK.Hepatoprotective activity of Cleome viscosa Linn. extract against thioacetamide-induced hepatotoxicity in rats. Nat Prod Res.2009 , 23[14]: 1289-97.

[11] Sarfaraz S, Najam R, Azhar I, Riaz B, Anser H. Anxiolytic and CNS depressant Effects of ethanolic Extract of Cleome brachycarpa revealed after Neuropharma-cological Screening. WJPS 2014.2[17]605-610.

[12] Afifi MS. Phytochemical and Biological Investigation of Cleome brachycarpa Vhel. Growing in Egypt. IJPSR, 2014; 5[9]): 4008-4014.

[13] WM, Lee Acetaminophen and the U.S. Acute Liver Failure Study Group: lowering the risks of hepatic failure. Hepatology 2004, 40[1], 6-9.

[14] Mc Clain CJ, Price S, Barres S, Devalarja R, Shedlofsky S. Acetaminophen-Induced Hepatotoxicity: a Comprehensive Update. J Clin Transl Hepatol.2016, 4[2], 131-42.

[15] Michaut A, Le Guillou D, Moreau C, Bucher S, McGill MR, Martinais S et al. A cellular model to study drug-induced liver injury in nonalcoholic fatty liver disease: Application to acetaminophen. Toxicol Appl Pharmacol. 2016, Feb. 292: 40-55.

[16] Sener G, Sehirli AO, Ayanoglu-Dulger G. Protective Effects of Melatonin, Vitamin E and Nacetyl Cysteine against Acetaminophen Toxicity in Mice: a Comparative Study. J. Pineal Res.2003, 35, 61-8.

[17] Yoon MY, Kim SJ, Lee BH, Chung JH, Kim YC. Effects of Dimethyl sulfoxide on Metabolism and Toxicity of Acetaminophen in Mice. Biological and Pharmaceutical Bulletin.2006 , 29, 1618-24.

[18] Lee KJ, You HJ, Park SJ, Kim JS. Hepatoprotective Effects of Platycodon grandiflorum on Acetaminophen Induced Liver damage in Mice. Cancer Letters.2001 , 174: 73-81.

[19] Gopi KS, Reddy AG, Jyothi K, Kumar BA. Acetaminophen-induced Hepato- and Nephrotoxicity and Amelioration by Silymarin and Terminalia chebula in Rats. Toxicol Int.2010, 17[2], 64-66.

[20] Sukhdev SH, Suman Preet SK, Gennaro L, Devdutt R. Extraction Technologies for Medicinal and Aromatic Plants. ICS-UNIDO.2008, 2[1], 22-51.

[21] Committee for the Update of Guide for the Care and Use of Laboratory Animals. Guide for the Care and Use of Laboratory Animals Guide for the Care and Use of Laboratory Animals. Washington, DC 20055 : THE NATIONAL ACADEMIES PRESS, 2010.

[22] Adeneye AA, Ajagbonna OP, Adeleke TI, Bello SO. Preliminary toxicity and phytochemical studies of the stem bark aqueous extract of Musanga cecropioides in rats. J Ethnopharmacol. 2006 May 24;105[3]:374-9.

[23] OECD Guidelines, TG 425. Guideline 425: Acute oral toxicity-Up-and-down procedure. [book auth.] OECD. OECD Guidelines for the Testing of Chemicals, Section 4. 2008, 4, 1-27.

[24] Okazaki K, Okazaki S, Nishimura S, Nakamura H, Kitamura Y, Hatayama K et al. "A repeated 28-day oral dose toxicity study of methoxychlor in rats, based on the'enhanced OECD test guideline 407'for screening endocrine-disrupting chemicals. Arch Toxicol. 2001 Nov;75(9):51321. 
[25] Forouzandeh H, Azemi ME, Rashidi I, Goudarzi M, Kalantari H.Study of the Protection Effect of Teucrium polium L. Extract on Acetaminophen- Induced Hepatotoxicity in Mice. IJPR.2013, 12[1], 123-29.

[26] Gaur K, Panda BB, Nema RK, Jain CP. Hepatoprotective activity of Jatropha gossypifolia against Carbon tetrachloride Induced Hepatic Injury in Rats. Asian J. Pharm. Clini. Res.2009, $1[2], 50-4$.

[27] Vandana P, Hardik A, Sudhamani S. Antioxidant and Hepatoprotective Effect of Garcinia indica fruit rind in ethanol- Induced Hepatic damage in Rodents. Interdiscip Toxicol.2012, 5[4], 20713.

[28] Reitman S, Frankel S. A colorimetric method for the determination of Serum levels of Glutamic Oxalo Acetic acid and Pyruvic acid Transaminases. Am. J. Clin. Pathol.1975 , 10: 394-99.

[29] Buege JA, Aust SD. Microsomal Lipid Peroxidation Methods in Enzymology. MEMJ.2002, 30[2], 302-10.

[30] Marklund S, Marklund G. Involvement of the superoxide anion radical in the autoxidation of pyrogallol and a convenient assay for superoxide dismutase. Eur J Biochem.1974, 47[3], 46974.

[31] L, Góth. A simple method for determination of serum Catalase activity and revision of reference range . Clin Chim Acta. 1991,196[2-3]: 143-51.

[32] Teo DC, Ng PS, Tan SH, Lim AT, Toh DS, Chan SY, et al. Drug-induced liver injury associated with Complementary and Alternative Medicine: a review of adverse event reports in an Asian community from 2009 to 2014. BMC Complement Altern Med. 2016 Jul 7;16:192

[33] Rudraiah S1, Manautou JE. From hepatoprotection models to new therapeutic modalities for treating liver diseases: a personal perspective. Version 2. F1000Res. 2016 Jul 14 [revised 2016 Jul 19];5. pii: F1000 Faculty Rev-1698.

[34] Mitchell R. McGill, Hartmut Jaeschke. Mechanistic Biomarkers in Acetaminophen-induced Hepatotoxicity and Acute Liver Failure: From Preclinical Models to Patients.Expert Opin Drug Metab Toxicol. 2014 Jul;10[7]:1005-17.

[35] Safhi MM, Alam MF, Khuwaja G, Islam F, Hussain S, Fageeh MM et al. Repeated Eexposure of sodium tellurite on the rat liver and on the potential mechanisms of the metalloid induced hepatotoxiicty.Acta Pol Pharm. 2016 May-Jun;73(3):675-82.

[36] Toppo R, Roy BK, Gora RH, Baxla SL, Kumar P.Hepatoprotective activity of Moringa oleifera against cadmium toxicity in rats. 4, 2015, Vet World. , Vol. 8, pp. 537-40.

[37] Bhoopat L1, Srichairatanakool S, Kanjanapothi D, Taesotikul T, Thananchai H, Bhoopat T. Hepatoprotective effects of lychee (Litchi chinensis Sonn.): a combination of antioxidant and anti-apoptotic activities. J Ethnopharmacol. 2011, 136[1], 55-6.

[38] Afifi, MS.Phytochemical and Biological Investigation of Cleome brachycarpa Vhel. Growing in Egypt. IJPSR 2014, 5[9]: 4008-14.

[39] Rao BS, Reddy KE,Parveen K, Narendra BL, Shekhar SC, Mangala L. Effects of Cleome viscosa on hyperalgesia, oxidative stress and lipid profile in STZ induced diabetic neuropathy in Wistar rats. Pak J Pharm Sci.2014, 27[5]:1137-45. 